\title{
THE EFFECT OF DIETARY METHIONINE LEVELS ON THE PERFORMANCE PARAMETERS OF ARCTIC FOXES (VULPES LAGOPUS)
}

\author{
Andrzej Gugołek ${ }^{1}$, Tomasz Wyczling ${ }^{1}$, Paweł Janiszewski , \\ Przemysław Sobiech ${ }^{2}$, Piotr Wyczling ${ }^{1}$, Małgorzata Konstantynowicz ${ }^{1}$ \\ ${ }^{1}$ Department of Fur-Bearing Animal Breeding and Game Management, University of Warmia and \\ Mazury in Olsztyn, Oczapowskiego 5, 10-718 Olsztyn, Poland \\ ${ }^{2}$ Department and Clinic of Internal Diseases, University of Warmia and Mazury in Olsztyn, \\ Oczapowskiego 14, 10-719 Olsztyn, Poland \\ Corresponding author: gugolek@uwm.edu.pl
}

\begin{abstract}
The objective of this study was to determine the effect of dietary inclusion levels of methionine and cystine on the performance traits and health status of Arctic foxes. The experimental material comprised 60 blue Arctic foxes of the Finnish type. Control group (C) animals were fed diets (CA and $\mathrm{CB}$ ) with standard concentrations of methionine and cystine. In experimental groups E1 and E2, methionine content was increased by approximately $2 \mathrm{~g}$ per $100 \mathrm{~g}$ total protein, relative to the recommended intake. Diets for group E1 were supplemented with liquid methionine (E1A and E1B), and diets for group E2 were supplemented with crystalline methionine (E2A and E2B). Diets A were offered during the growing period, and diets B were administered during the furring period. During the growing period, methionine + cystine levels in diets $\mathrm{E} 1$ and $\mathrm{E} 2$ were $4.19+0.59 \mathrm{~g}$ and $4.22+0.53 \mathrm{~g}$ per $100 \mathrm{~g}$ total protein, respectively. During the furring period, methionine+cystine levels were $4.83+0.68 \mathrm{~g}$ in diets $\mathrm{E} 1$ and $4.91+0.61 \mathrm{~g}$ in diets $\mathrm{E} 2$. The body weights of Arctic foxes were determined, their body conformation was evaluated, and the duration of the rearing period was calculated. Blood samples for morphological and biochemical analyses were collected from animals aged 24 weeks, selected randomly from each group. After slaughter, pelt length and fur quality were determined in accordance with the International Trading System. The results of this study indicate that diets for Arctic foxes should be supplemented with methionine. The experimental diets contributed to improving the performance traits of foxes, in particular fur quality, and they had no adverse influence on the health status of animals. It may be concluded that farmraised Arctic foxes of the Finnish type show an increased demand for methionine.
\end{abstract}

Key words: Vulpes lagopus, nutrition, methionine, performance parameters, health status

Carnivorous fur animals are fed considerable amounts of animal by-products which, combined with an inadequately balanced diet, may lead to amino acid deficiency. In the nutrition of fur-bearing animals, a particularly important role is played by sulfur amino acids considered limiting, methionine and cystine (Dahlman et al., 
2004). Research investigating the nutritional implications of methionine and related amino acids in fur animals has shown that increased dietary methionine levels improve the growth performance and fur quality of Arctic foxes (Dahlman et al., 2002; Lorek et al., 2002 b; Dahlman et al., 2003; Przysiecki et al., 2003/2004; Dahlman et al., 2004; Matusevicius et al., 2004). The above suggests that the demand for sulfurcontaining amino acids in farmed foxes may be higher than expected, probably due to higher productivity resulting from genetic progress. Finnish giant foxes raised nowadays are characterized by greater body size and thicker fur than those raised in the past (Valkosalo, 1987; Peuria et al., 2005). The optimal concentrations of sulfur amino acids in fox diets remain unknown. The amino acid content of the ration is determined by amino acid concentrations in feed components. Thus, it would be difficult to extrapolate the findings from Scandinavian studies to Polish fox farms, since in Scandinavia the ration is based on fish products and in Poland the main diet component are poultry by-products.

The objective of this study was to determine the effect of increased dietary inclusion levels of methionine on the performance traits and health status of Arctic foxes.

\section{Material and methods}

The experimental material comprised 60 blue Arctic foxes of the Finnish type, aged 10 weeks. The foxes were divided into three equal groups, identical in terms of origin and sex (10 males and 10 females), and were placed in standard cages (two animals per cage). The experiment was carried out under production conditions, on a fox farm located in the Pomorskie Province (Poland). The animals had free access to feed and water. The diets were formulated using typical feed components available in Poland. The energy and nutritive value of diets was comparable. All diets met the nutrient requirements of growing foxes (Nutrient Requirements..., 1994) (Table 1). The experimental factor was methionine concentration in the ration. Control group (C) animals were fed diets (CA and $\mathrm{CB}$ ) in which the recommended levels of methionine and cystine (Nutrient Requirements..., 1994) were maintained through careful selection of ingredients, using diet formulation and optimization software (Mroczko and Sobek, 2003). Diet composition was validated by chemical analysis at 14-day intervals.

In experimental groups E1 and E2, methionine content was increased by approximately $2 \mathrm{~g}$ per $100 \mathrm{~g}$ total protein, relative to the recommended intake. Diets for group E1 were supplemented with liquid methionine (E1A and E1B), and diets for group E2 were supplemented with crystalline methionine (E2A and E2B). Diets A were offered during the growing period (from the beginning of the experiment to 15 September), and diets B were administered during the furring period (from 16 September to slaughter). Based on the results of analyses, adequate amounts of synthetic methionine were added to diets. The calculations were performed on a pure ingredient basis (crystalline and liquid methionine containing 99\% and 88\% pure ingredient, respectively). The average amino acid levels in diets are presented in Table 2. 
Amino acids were determined using the Biochrom 20 plus amino acid analyser and Biochrom amino acid analysis reagents (Biochrom Ltd., Cambridge, England). The following Sigma amino acid standards were used: Amino Acid Standard Solution (AASS-18), L-methionine sulfone, L-cysteic acid, L-norleucine, L-tryptophan.

Table 1. Composition (\%) and nutritive value of diets

\begin{tabular}{l|c|c}
\hline \multirow{2}{*}{\multicolumn{1}{c}{ Components }} & \multicolumn{2}{c}{ Period } \\
\cline { 2 - 3 } & growing $(\mathrm{A})$ & furring $(\mathrm{B})$ \\
\hline Hard filleted cod by-products & 10.2 & 4.2 \\
Hard poultry by-products & 17.6 & 17.5 \\
Soft poultry by-products & 35.5 & 35.5 \\
Beef bones & 5.2 & 1.5 \\
Cooked poultry blood & 5.2 & 2.0 \\
Meat and bone meal & 3.2 & 7.4 \\
Sour milk & 0.5 & 0.5 \\
Extruded barley & 1.3 & 1.5 \\
Ground wheat & 7.7 & 6.9 \\
Wheat bran & 0.4 & 0.2 \\
Steamed potatoes & - & 7.4 \\
Vegetable oil & 0.3 & 0.3 \\
Water* & 12.9 & 14.8 \\
Total & 100.0 & 100.0 \\
Vitamin and mineral supplement & $1 \mathrm{~kg} / \mathrm{t}$ & $1 \mathrm{~kg} / \mathrm{t}$ \\
Energy percentage from: & & 34 \\
protein & 38 & 47 \\
$\quad$ cat & 46 & 19 \\
ME in MJ/kg diet & 16 & 5.048 \\
\hline
\end{tabular}

* Water used for steam treatment and for mixing with feed.

The body weights of foxes were determined at the beginning and at the completion of the experiment, prior to feeding, on an individual basis, accurate to $0.1 \mathrm{~kg}$, using an indicating scale. At the end of the furring period, the body conformation of foxes was evaluated according to the Arctic Fox Standard (1999). The duration of the rearing period was calculated as the number of days from birth to slaughter. The animals were slaughtered at an optimal time, i.e. after their coats had fully developed.

Blood samples (approx. $5 \mathrm{ml}$ ) for morphological and biochemical analyses were collected from the small saphenous vein of animals aged 24 weeks. The analyses were performed by standard methods (AOAC, 1990). Blood samples were collected once only, since the morphological and biochemical parameters of properly selected 
experimental animals should not vary at the start of the experiment, and unnecessary stress should be avoided in line with the Ethics Committee recommendations. Red blood cell (RBC) counts, mean corpuscular volume (MCV), red blood cell distribution width (RDW), white blood cell (WBC) counts, haemoglobin (HBG), haematocrit (HCT), mean corpuscular haemoglobin $(\mathrm{MCH})$, mean corpuscular haemoglobin concentrations (MCHC), glucose (GLU) and urea (UREA) levels, the activity of creatine kinase $(\mathrm{CK})$, alanine aminotransferase (ALT) and aspartate aminotransferase (AST) were determined.

Pelts were processed by universally applied methods, and they were graded by size, quality and appearance in accordance with the International Trading System. For comparative purposes, the grades were denoted by numbers: Saga $-1, \mathrm{~B}-2$, C -3 (Fox pelt..., 1994).

The data were processed statistically by one-way analysis of variance in an orthogonal design (Statistica PL, 2007).

\section{Results}

In the present study, methionine+cystine levels in diets E1 and E2 were 4.19+0.59 $\mathrm{g}$ and $4.22+0.53 \mathrm{~g}$ per $100 \mathrm{~g}$ total protein, respectively during the growing period, and $4.83+0.68 \mathrm{~g}$ and $4.91+0.61 \mathrm{~g}$ per $100 \mathrm{~g}$ total protein, respectively during the furring period (Table 2 ).

Table 2. Amino acid composition of diets ( $\mathrm{g} / 100 \mathrm{~g}$ total protein)

\begin{tabular}{|c|c|c|c|c|c|c|}
\hline \multirow{3}{*}{ Amino acids } & \multicolumn{6}{|c|}{ Period/Diets } \\
\hline & \multicolumn{3}{|c|}{ growing A } & \multicolumn{3}{|c|}{ furring $\mathrm{B}$} \\
\hline & $\mathrm{C}$ & E1 & E2 & $\mathrm{C}$ & E1 & E2 \\
\hline Aspartic acid & 8.21 & 8.19 & 7.73 & 8.11 & 8.02 & 8.33 \\
\hline Threonine & 3.71 & 3.60 & 3.67 & 3.77 & 3.63 & 3.69 \\
\hline Serine & 3.79 & 4.07 & 3.72 & 3.86 & 4.01 & 3.97 \\
\hline Glutamic acid & 15.15 & 15.13 & 14.80 & 15.33 & 15.27 & 14.97 \\
\hline Proline & 8.89 & 10.00 & 8.98 & 8.82 & 10.32 & 9.88 \\
\hline Cystine & 0.58 & 0.59 & 0.53 & 0.62 & 0.68 & 0.61 \\
\hline Glycine & 9.65 & 10.73 & 9.43 & 9.77 & 10.48 & 9.71 \\
\hline Alanine & 6.47 & 6.70 & 6.40 & 6.51 & 6.63 & 6.48 \\
\hline Valine & 4.23 & 4.11 & 4.21 & 4.12 & 4.03 & 4.05 \\
\hline Methionine & 2.03 & 4.19 & 4.22 & 2.93 & 4.83 & 4.91 \\
\hline Isoleucine & 3.35 & 3.10 & 3.26 & 3.27 & 3.17 & 3.29 \\
\hline Leucine & 6.52 & 6.08 & 6.36 & 6.68 & 6.27 & 6.51 \\
\hline Tyrosine & 3.44 & 3.35 & 3.35 & 3.56 & 3.46 & 3.46 \\
\hline Phenylalanine & 4.77 & 4.66 & 4.65 & 4.81 & 4.52 & 4.69 \\
\hline Histidine & 2.66 & 2.61 & 2.54 & 2.59 & 2.65 & 2.61 \\
\hline Lysine & 4.98 & 4.36 & 4.81 & 4.87 & 4.43 & 4.68 \\
\hline Arginine & 6.57 & 5.55 & 6.33 & 6.71 & 5.71 & 6.55 \\
\hline Tryptophan & 1.05 & 1.03 & 1.12 & 1.11 & 1.09 & 1.14 \\
\hline
\end{tabular}


Table 3. Performance traits of foxes $($ mean \pm Sd)

\begin{tabular}{|c|c|c|c|}
\hline \multirow{2}{*}{ Item } & \multicolumn{3}{|c|}{ Group } \\
\hline & $\mathrm{C}$ & E1 & E2 \\
\hline \multicolumn{4}{|l|}{ Body weight (kg): } \\
\hline initial (10 weeks) & $2.39 \pm 0.56$ & $2.41 \pm 0.55$ & $2.36 \pm 0.58$ \\
\hline final (26 weeks) & $10.99 \pm 1.85$ & $11.47 \pm 1.43$ & $11.25 \pm 1.22$ \\
\hline \multicolumn{4}{|l|}{ Body conformation (points:) } \\
\hline trunk length $(\mathrm{cm})$ & $71.65 \pm 3.51$ & $70.40 \pm 3.55$ & $71.10 \pm 4.54$ \\
\hline body size and constitution & $6.00 \pm 0.00$ & $6.00 \pm 0.00$ & $5.80 \pm 0.89$ \\
\hline colour type & $2.85 \pm 0.37$ & $2.85 \pm 0.37$ & $2.80 \pm 0.41$ \\
\hline colour purity & $2.55 \pm 0.51$ & $2.55 \pm 0.51$ & $2.65 \pm 0.49$ \\
\hline fur quality & $5.30 \pm 1.49 \mathrm{~B}$ & $6.40 \pm 1.39 \mathrm{~A}$ & $6.15 \pm 1.14$ \\
\hline total score & $16.70 \pm 1.72 \mathrm{~B}$ & $17.80 \pm 1.77 \mathrm{~A}$ & $17.40 \pm 1.43$ \\
\hline Duration of the rearing period (days) & $203.00 \pm 9.15 \mathrm{~A}$ & $198.20 \pm 6.39$ & $196.05 \pm 7.65 \mathrm{~B}$ \\
\hline \multicolumn{4}{|l|}{ Pelt evaluation: } \\
\hline pelt length $(\mathrm{cm})$ & $124.60 \pm 4.19$ & $128.20 \pm 5.23$ & $125.20 \pm 5.07$ \\
\hline pelt quality & $1.50 \pm 0.52$ & $1.44 \pm 0.65$ & $1.48 \pm 0.44$ \\
\hline
\end{tabular}

A, $\mathrm{B}-$ values in rows with different letters differ significantly $(\mathrm{P} \leq 0.01)$.

There were no statistically significant differences in the average initial body weight of Arctic foxes between groups. The body weights of animals at 26 weeks were also similar, but experimental group foxes were slightly heavier. The average body weights of foxes at slaughter were as follows: group C $-10.99 \mathrm{~kg}, \mathrm{E} 1-11.47$ $\mathrm{kg}, \mathrm{E} 2-11.25 \mathrm{~kg}$ (Table 3). In week 26, body weight variation within experimental groups was lower, as manifested in standard deviations $(\mathrm{Sd})$, thus pointing to a similar response of the animals to the experimental factor.

Group $\mathrm{C}$ and E1 foxes received the maximum score for body size and conformation (6.0 points), while group E2 animals got 5.8 points. Trunk length was comparable in all groups, ranging from 70.40 to $71.65 \mathrm{~cm}$. Dietary methionine supplementation had no effect on colour type and coat colour purity, since both traits are genetically determined and only slightly modified by environmental factors.

The most important attribute of fur is its quality. The furs of group E1 foxes, fed liquid methionine, were characterized by the highest quality, 1.1 points higher than in group $\mathrm{C}$ (significant difference) and 0.85 points higher than in group E2 (nonsignificant difference). In the present study, the total score for body conformation was higher in experimental groups. A statistically significant difference was noted between group $\mathrm{C}$ and group E1, due to a higher score for fur quality in the latter.

The rearing period was significantly longer in group C (203 days), compared with groups E1 and E2 (198.20 and 196.05 days, respectively), which suggests that methionine supplementation accelerated fur growth by 5-7 days.

Pelt length was similar in all groups, but a trend towards longer pelts was observed in experimental groups. Average pelt length was $124.6 \mathrm{~cm}$ in control group $\mathrm{C}, 128.2 \mathrm{~cm}$ in experimental group E1 and $125.2 \mathrm{~cm}$ in experimental group E2. The quality of pelts in group E1 was closest to the highest grade, Saga (1). 
Table 4. Blood morphological and biochemical parameters (mean \pm Sd)

\begin{tabular}{l|c|c|c}
\hline \multirow{2}{*}{ Item } & \multicolumn{3}{c}{ Group } \\
\cline { 2 - 4 } & $10.38 \pm 1.40$ & E1 & E2 \\
\hline WBC $\left(10^{12} / \mathrm{l}\right)$ & $8.09 \pm 0.71$ & $8.34 \pm 2.48$ & $10.10 \pm 0.25$ \\
RBC $\left(10^{12} / \mathrm{l}\right)$ & $15.56 \pm 1.58$ & $16.76 \pm 1.80$ & $9.17 \pm 0.55$ \\
HGB (mmol/l) & $45.40 \pm 4.27$ & $48.74 \pm 6.35$ & $17.54 \pm 0.73$ \\
HCT (1/l) & $182.40 \pm 53.59$ & $215.80 \pm 73.26$ & $31.30 \pm 2.73$ \\
PLT (10/l) & $56.20 \pm 1.48$ & $57.00 \pm 1.58$ & $56.00 \pm 1.41$ \\
MCV (fl) & $19.24 \pm 0.59$ & $19.68 \pm 0.63$ & $19.16 \pm 0.71$ \\
MCH (pg) & $34.26 \pm 0.58$ & $34.48 \pm 0.90$ & $34.24 \pm 0.63$ \\
MCHC (g/dl) & $14.64 \pm 0.53$ & $14.14 \pm 0.63$ & $14.60 \pm 0.77$ \\
RDW (\%) & $12.28 \pm 0.65$ & $12.06 \pm 2.00$ & $11.96 \pm 1.80$ \\
MPV (\%) & $148.80 \pm 98.78$ & $253.40 \pm 199.15$ & $295.80 \pm 175.02$ \\
GLU (mg/dl) & $50.48 \pm 10.03$ & $50.52 \pm 12.42$ & $36.02 \pm 12.81$ \\
UREA (mg/dl) & $919.75 \pm 490.79 \mathrm{a}$ & $412.32 \pm 307.76 \mathrm{~b}$ & $500.36 \pm 407.31$ \\
CK (U/l) & $280.33 \pm 60.38$ & $156.50 \pm 43.13$ & $249.43 \pm 216.67$ \\
AST (U/l) & $480.60 \pm 290.74 \mathrm{a}$ & $284.60 \pm 203.77 \mathrm{~b}$ & $284.20 \pm 237.34 \mathrm{~b}$ \\
ALT (U/l) &
\end{tabular}

$\mathrm{a}, \mathrm{b}$ - values in rows with different letters differ significantly $(\mathrm{P} \leq 0.05)$.

Table 4 presents blood morphological and biochemical parameters in Arctic foxes aged 24 weeks. Increased dietary methionine concentrations had no significant effect on blood morphology (despite certain differences), which indicates that experimental feeding had no negative impact on the health status of animals. Foxes fed methionine-supplemented diets had elevated haemoglobin levels, which may suggest that this amino acid positively influenced haematopoiesis. Serum glucose levels were lower in control group $\mathrm{C}(148.8 \mathrm{mg} / \mathrm{dl})$ than in groups E1 and E2, thus indicating that methionine had a beneficial effect on carbohydrate metabolism. Considerable differences were observed between groups with respect to enzymatic activity levels. In foxes not supplemented with methionine, serum creatine kinase concentrations were two-fold higher (919 U/1) than in the other groups. Lower CK activity in animals fed methionine-supplemented diets suggests that methionine exerted a protective effect on muscle tissue, since $\mathrm{CK}$ activity is a specific indicator of muscle damage. The activity levels of alanine aminotransferase (ALT) and aspartate aminotransferase (AST) were also higher in control group foxes, and the increase in ALT activity was more profound.

\section{Discussion}

The final body weights of foxes noted in our study may be considered typical of Finnish giants under local production conditions. According to Kubacki (2000), the body weight of foxes is determined by their origin. In the cited study, the average 
body weight of Arctic foxes of the Finnish type at slaughter was $10.80 \mathrm{~kg}$, while in a later experiment (Kubacki, 2002) it reached $11.42 \mathrm{~kg}$. Dietary methionine supplementation is believed to enhance protein synthesis in the body and stimulate weight gain. As demonstrated by Bieguszewski et al. (1979), methionine and lysine positively affect the growth rate of Arctic foxes. According to Dahlman et al. (2002), low dietary levels of methionine and lysine inhibit the growth and development of foxes. In a study by Lorek et al. (2002 b), dietary methionine supplementation at $2 \mathrm{~g}$ per $100 \mathrm{~g}$ total protein increased the final body weights of Arctic foxes by $0.45 \mathrm{~kg}$.

Similar results of body size and conformation were reported by other authors. In a study by Dahlman et al. (2002), the average trunk length of blue foxes was $69-72 \mathrm{~cm}$.

An increase in fur quality correlated with an increase in dietary methionine levels has also been observed by other authors. Rajs and Bednarek (1994) demonstrated that methionine increased fur thickness in Arctic foxes. According to Zoń et al. (2000), a diet ensuring a good amino acid balance has a beneficial influence on fur quality in blue foxes, and fur thickness is particularly affected by methionine. Lorek et al. (2002 b) also reported better fur quality in foxes fed diets with increased methionine concentrations, evaluated in vivo.

The pelt length was similar in group $\mathrm{C}$ and in experimental groups. This length is also determined by handling and stretching. An increase in pelt size is correlated with an increase in the final body weights of foxes and body conformation scores. The pelt length noted in our experiment was comparable with that reported by Scandinavian researchers - in a study by Dahlman et al. (2002), average pelt length was in the $116-122 \mathrm{~cm}$ range.

The results of fur quality assessment were consistent with body conformation scores, which is quite natural given that overall pelt appearance is significantly affected by fur parameters. Zoń et al. (2000), Lorek et al. (2002 b), Dahlman et al. (2003), and Przysiecki et al. (2003/2004) demonstrated that pelt quality was higher in blue foxes fed diets supplemented with synthetic methionine. Dahlman et al. (2002) reported that in blue foxes supplementary methionine had a more beneficial influence on fur thickness than lysine.

The results of blood tests were comparable with those reported by other authors (Lorek et al., 2002 a; Kopczewski et al., 2002; Lorek et al., 2005; Saba et al., 2008). In a study by Lorek et al. (2002 a), RBC was $8.75 \mathrm{U} / 1$ in foxes fed pellets, i.e. very similar to the value noted in our experiment.

In an experiment conducted by Saba et al. (2008), serum glucose concentrations varied from 102.6 to $109.1 \mathrm{mg} / \mathrm{dl}$. Urea levels, which ranged from 36 to $50 \mathrm{U} / \mathrm{I}$, were lower than reported by Kopczewski et al. (2002), and showed no significant differences due to considerable variation. In a study by Lorek et al. (2005), synthetic methionine had no effect on serum urea levels.

The ALT and AST enzymes are liver-specific, and the observed changes in their activity show that methionine contributed to regulating metabolism in the liver and supported liver function in foxes. Comparable results were obtained by Fau et al. (1987) in other carnivorous animals, namely cats, and by Rana and Chauhan (2000) in rats. 
The experimental diets contributed to improving the performance traits of foxes, in particular fur quality, and they had no adverse influence on the health status of animals. The above indicates that Arctic foxes of the Finnish type show an increased demand for methionine, compared with the animals raised in previous years. Liquid methionine, used in our experiment, is ready to use, easy to administer and has a beneficial effect on production results. This amino acid helps protect muscle and liver tissue, thus indirectly affecting the performance parameters of foxes.

\section{References}

AOAC (1990). Official Methods of Analysis of the Association of Official Analytical Chemists, 15th ed., Arlington.

Arctic Fox Standard (1999). Central Animal Breeding Office, Warszawa.

B i eguszewski H., Gruda-Śmigiel M., Wislopolski A. (1979). The effect of supplementing protein-deficient diets with methionine and lysine on body weight, nutrient digestibility and selected blood parameters in Arctic foxes (in Polish). Zesz. Nauk. ATR Bydgoszcz, Zoot., 5: $280-284$.

D a hl man T., V a la j a J., N i e m e l a P., J a l a a T. (2002). Influence of protein level and supplementary L-methionine and lysine on growth performance and fur quality of blue fox (Alopex lagopus). Acta Agr. Scand. A-An., 52: 174-182.

Dahlman T., Valaja J., Jalava T., Skrede A. (2003). Growth and fur characteristics of blue fox (Alopex lagopus) fed diets with different protein levels and with or without DL-methionine supplementation in the growing-furring period. Canadian J. Anim. Sci., 83 (2): 239-245.

D a $1 \mathrm{~m}$ an T., Val a ja J., V en a la in en E., J a la va T., P a lo nen I. (2004). Optimum dietary amino acid pattern and limiting order of some essential amino acids for growing-furring blue foxes (Alopex lagopus). Anim. Sci., 78 (1): 77-86.

F a u D., Morris J.G., Roger s Q.R. (1987). Effects of high dietary methionine on activities of selected enzymes in the liver of kittens (Felis domesticus). Comp. Biochem. Phys., 88 (2): 551-555.

Kopczewski A., B is-Wencel B., Saba L., Sławoń J., Ondrasovic M., Wnuk W. (2002). Effects of varying levels of feeding high-energy diets and antioxidants on serum biochemical parameters in the Arctic fox. Vet. Med., 58: 616-619.

K u b a c k i P. (2000). A comparison of selected performance traits of R1 and R2 Arctic foxes (Alopex lagopus) produced by mating Polish females with males imported from Finland (in Polish). Zesz. Nauk. Prz. Hod., 53: 73-78.

Kubacki P. (2002). Body weight characteristics of Arctic foxes (Alopex lagopus L.) of different genotypes (in Polish). Zesz. Nauk. Prz. Hod., 64: 103-110.

Lorek M.O., Gugołek A., Hartman A. (2002 a). Effect of feeding pellets to Arctic foxes on their performance and selected morphological-biochemical blood indices. Czech J. Anim. Sci., 47 (8): $333-338$.

Lor ek M.O., Hartman A., Gug ołek A. (2002 b). The effect of dietary amino acid levels on the performance traits of Arctic foxes (in Polish). Zesz. Nauk. Prz. Hod., 64: 111-118.

Lorek M.O., Hartman A., Gugołek A., Matusevicius P. (2005). Effects of synthetic amino acids on morphological and biochemical blood parameters and health status of Arctic foxes. Vet. Zootec., 30 (52): 54-59.

Matusevicius P., Januskievicius A., Gugołek A., Zilinskiene A. (2004). The effect of use of synthetic methionine in foxes (Alopex logopus L.). Vet. Zootec., 25 (47): 71-75.

P e ur i a J., S t an d e n J., M a n t y s a ar i a E.A. (2005). Genetic parameters in Finnish blue fox population: Pelt characters and live animal grading traits. Acta Agr. Scand. A-An., 55 (4): 137-144.

Przys iecki P., Nowicki S., Nawrocki Z., Paw lak F., Potkański A. (2003/2004). The effect of diet supplementation with synthetic methionine on selected performance traits and fur quality of Arctic foxes (in Polish). Rocz. Nauk. AR Poznań, 55: 3-10. 
R a j s R., B e d n a re k T. (1994). The effect of vitamin $B_{12}$ injections and dietary methionine supplementation on serum vitamin $B_{12}$ levels and body conformation in Arctic foxes (in Polish). Zesz. Nauk. Prz. Hod., 15: 83-89.

$\mathrm{R}$ a $\mathrm{n}$ a S.V.S., $\mathrm{Ch}$ a u h a $\mathrm{A}$ A. (2000). Influence of methionine and zinc on liver collagen in molybdenotic rats. Relationship with lipid peroxidation. Biol. Trace Elem. Res., 73 (1): 85-91.

S ab a L., Likos-Grzesiak B., N ow ak ow i c z-D ębek B., B is - W ence 1 H., Marty na J., W n u k W. (2008). Effect of synthetic antioxidant on biochemical indices in blood of Arctic fox (Alopex lagopus). Ann. UMCS, Sec. EE, XXVI (3): 3-18.

V a 1 k o s a 1 o K. (1987). Fins blavaev i syperformat. Dansk Pelsdyraval., 10: 759-761.

Zoń A., Sła woń J., B i elańsk i P., Z a jąc J., P i órkowska M. (2000). The effect of feeding regime on fur quality in blue foxes (in Polish). Rocz. Nauk. Zoot., Supl., 6: 314-317.

Accepted for printing 29 II 2012

\title{
ANDRZEJ GUGOŁEK, TOMASZ WYCZLING, PAWEŁ JANISZEWSKI, PRZEMYSŁAW SOBIECH, PIOTR WYCZLING, MAŁGORZATA KONSTANTYNOWICZ
}

\author{
Wpływ poziomu metioniny w dawkach pokarmowych na wskaźniki użytkowe lisów polarnych \\ (Vulpes lagopus)
}

\section{STRESZCZENIE}

Celem badania była ocena wpływu poziomu metioniny i cystyny w dawkach pokarmowych lisów polarnych na ich wskaźniki użytkowe i stan zdrowotny. Badania przeprowadzono na 60 lisach polarnych niebieskich typu fińskiego. Zwierzęta grupy kontrolnej (C) otrzymywały mieszanki paszowe (CA i CB), w których poziom metioniny i cystyny utrzymywano na tradycyjnie zalecanym poziomie. W grupach doświadczalnych E1 i E2 poziom metioniny podniesiono o około $2 \mathrm{~g} / 100 \mathrm{~g}$ białka ogólnego powyżej zaleceń. W grupie E1 dodawano metioninę w formie płynnej (dawki E1A, E1B), a w E2 metioninę krystaliczną (dawki E2A, E2B). Dawki oznaczone symbolem A podawano w okresie wzrostu i rozwoju, a oznaczone symbolem B w okresie kształtowania okrywy włosowej. W okresie wzrostu poziom metioniny+cystyny wynosił odpowiednio w grupach: E1 - 4,19+0,59, E2 - 4,22+0,53 g, natomiast w okresie kształtowania okrywy włosowej odpowiednio w grupach E1 - 4,83+0,68, E2 - 4,91+0,61 g na $100 \mathrm{~g}$ białka ogólnego. Podczas badań wykonano pomiary masy ciała, ocenę pokroju, obliczono także długość okresu odchowu. Od zwierząt z każdej grupy pobrano w wieku 24 tyg. krew do badań morfologicznych i biochemicznych. Po uboju zwierząt ich skóry oceniono zgodnie z międzynarodowym systemem aukcyjnym. Analizując uzyskane wyniki wykazano celowość suplementacji dawek metioniną. Eksperymentalne żywienie lisów polarnych spowodowało poprawę parametrów użytkowych, szczególnie jakości okrywy włosowej, a nie wpłynęło negatywnie na stan zdrowotny zwierząt. Świadczy to o wyższym niż zakładano zapotrzebowaniu lisów polarnych typu fińskiego na metioninę. 